\title{
PENENTUAN BATAS PENGELOLAAN LAUT DENGAN METODE KARTOMETRIK (Studi Kasus : Sengketa Pulau Berhala)
}

\author{
Yuwono $^{1}$, MeiriskaYusfania ${ }^{2}$, Rhaisang Al Iman Taufiqul Hakim Genena ${ }^{3}$ \\ 1,2,3 Teknik Geomatika, FTSLK-ITS Sukolilo, Surabaya 60111, Indonesia \\ Email: yuwono@geodesy.its.ac.id
}

\begin{abstract}
Abstrak
Indonesia merupakan negara kepulauan yang terbentang dari Sabang sampai Merauke. Kondisi tersebut dapat mendatangkan keuntungan dan juga ancaman bagi Negara Kesatuan Republik Indonesia. Salah satu ancaman yang dapat timbul adalah mengenai permasalahan batas, baik di darat maupun di laut. Salah satu permasalahan batas di laut yaitu sengketa antara Provinsi Jambi dan Provinsi Kepulauan Riau terkait dengan kepemilikan Pulau Berhala. Wilayah yang menjadi kajian dalam penelitian ini adalah Pulau Berhala yang berada di antara Provinsi Jambi , terletak pada $0^{\circ} 45^{\prime}-2^{\circ} 45^{\prime}$ Lintang Selatan dan $101^{\circ} 10^{\prime}-104^{\circ} 55^{\prime}$ Bujur Timur dan Provinsi Kepulauan Riau yang terletak pada $1^{\circ} 10$ Lintang Selatan - $5^{\circ} 10^{\prime}$ Lintang Utara dan $102^{\circ} 50^{\prime}-109^{\circ} 20^{\prime}$ Bujur Timur. Penarikan batas sejauh 12 mil laut untuk wilayah kewenangan provinsi sesuai dengan Permendagri Nomor 76 Tahun 2012 diperoleh dengan buffering menggunakan Arc GIS 10.2. Penarikan garis batas secara kartometrik menggunakan metode median line. Dari hasil pengolahan data dan analisa didapatkan tiga alternatif penarikan batas antara Provinsi Jambi dan Provinsi Kepulauan Riau.
\end{abstract}

Kata Kunci : Kartometrik, Median Line, Pemendagri , Pulau Berhala.

\section{PENDAHULUAN}

Indonesia tersusun dari ribuan pulau besar dan kecil yang terhubung oleh berbagai selat dan laut. Terdapat 13.466 pulau yang telah terdaftar dan memiliki koordinat (BIG,2014). Banyaknya Pulau dapat mendatangkan keuntungan sekaligus ancaman bagi kedaulatan Negara Indonesia. Ancaman yang dapat timbul salah satunya berkaitan dengan sengketa batas wilayah laut. Hal tersebut dapat terjadi karena tidak adanya batas yang jelas di laut. Sengketa bisa terjadi dengan negara lain maupun antar provinsi dan kabupaten di Indonesia. Sehingga diperlukan upaya melakukan penentuan batas wilayah laut untuk menghindari dan menyeesaikan sengketa tersebut. Terbentuknya Kepulauan Riau menjadi provinsi baru dengan berdasarkan pada UU No. 25 Tahun 2002 membuat klaim atas kepemilikan Pulau Berhala semakin meningkat. Menanggapi sengketa yang terjadi Menteri Dalam Negeri menetapkan Pulau Berhala dalam keadaan status quo. Menteri Dalam Negeri mengeluarkan suratnya Nomor 125.1/799/SJ, tertanggal 24 April 2006 untuk memperkuat kondisi status quo Pulau Berhala. Tanpa memperdulikan status quo yang disampaikan Menteri Dalam Negeri Provinsi
Kepulauan Riau terus melakukan aktifitas pembangunan fisik di Pulau Berhala. Sedangkan Pemerintah Provinsi Jambi memilih untuk menghargai dan menaati keputusan Menteri Dalam Negeri. Tindakan yang dilakukan oleh Pemerintah Provinsi Jambi diperkuat dengan tidak jadinya Pemerintah Provinsi Jambi mencairkan dana yang sudah dianggarkan dalam APBD Provinsi Jambi tahun 2006, untuk pembangunan dan pemberdayaan masyarakat Pulau Berhala. Drs. H. Zulkifli Nurdin sebagai Gubernur Jambi yang menjabat mulai tahun 2005 sampai 2010 juga melarang Bupati Tanjung Jabung Timur melakukan aktifitas pembangunan fisik Pulau Berhala(Abdullah,2012).

Untuk mendapatkan solusi dari sengketa perebutan Pulau Berhala diperlukan adanya kajian mengenai penentuan batas wilayah laut daerah antara Provinsi Jambi dengan Kepulauan Riau dilakukan dengan menggunakan metode kartometrik. Sebagai dasar melakukan kajian batas daerah ini mengacu pada hukum yang berlaku di Indonesia yaitu Permendagri Nomor 76 Tahun 2012 (Permendagri,2012). 


\section{METODOLOGI PENELITIAN}

Lokasi penelitian ini mengambil wilayah antara Provinsi Jambi dengan Provinsi Kepulauan Riau. Provinsi Jambi terletak pada 045' sampai dengan 2045’ Lintang Selatan dan 10110' sampai dengan 104055' Bujur Timur. Sedangkan Provinsi Kepulauan Riau terletak pada 1010 Lintang Selatan sampai dengan 5010' Lintang Utara dan 10250' sampai dengan 10920' Bujur Timur.

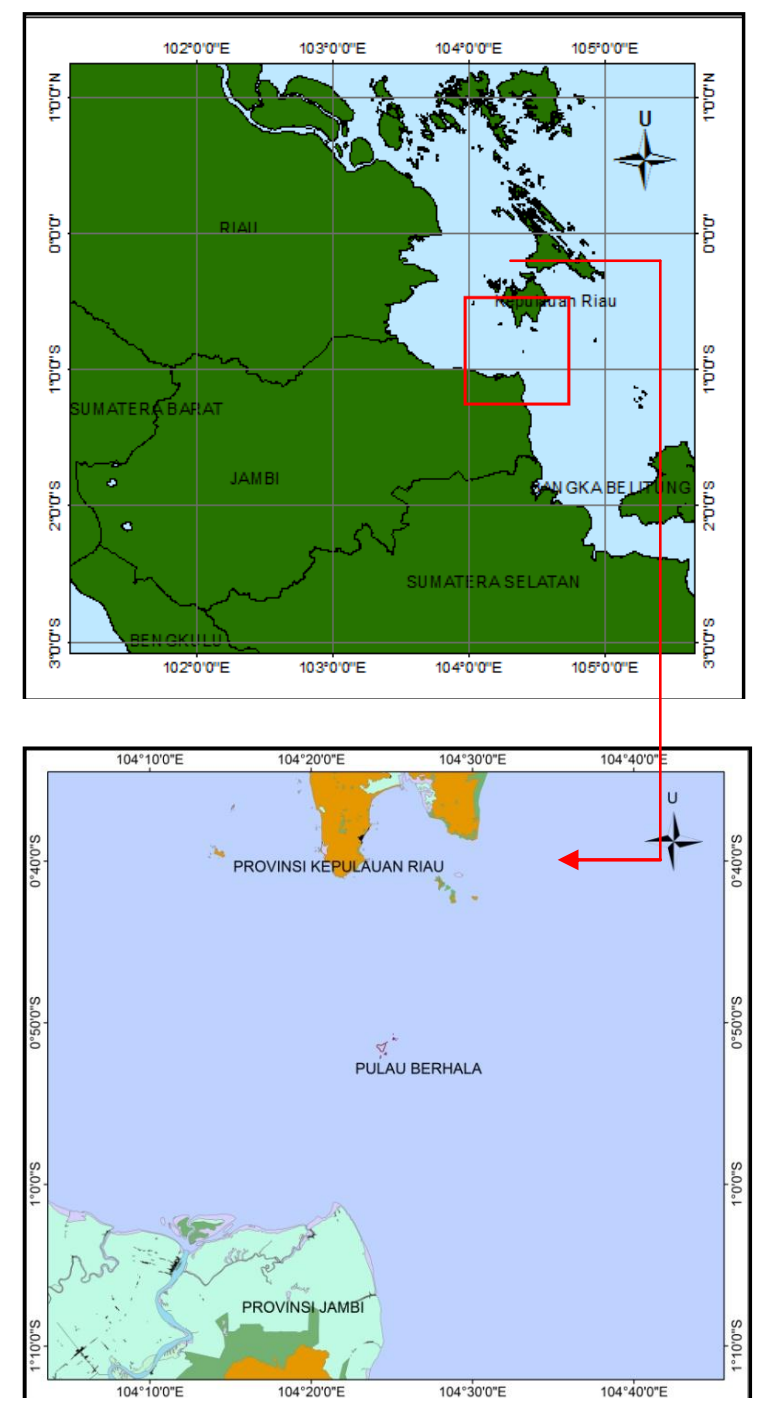

Gambar 1 Lokasi Penelitian

Bahan yang digunakan dalam penelitian ini adalah:

1. Peta Lingkungan Pantai (LPI) dari Badan Informasi Geospasial (BIG) dalam bentuk shapefile (*.shp).
2. Peta Rupa Bumi Indonesia (data toponimi, tutupan lahan, dan administrasi) dari Badan Informasi Geospasial (BIG) dalam bentuk shapefile (*.shp) dengan skala $1: 50.000$.

3. Peraturan Menteri Dalam Negeri Nomor 76 Tahun 2012

4. Data dan informasi pendukung terkait informasi sengketa Pulau Berhala.

Adapun peralatan penelitian yang digunakan dalam penelitian ini adalah perangkat keras (hardware) yang berupa Laptop digunakan dalam pengolahan data dan perangkat lunak untuk pengolah data .

Data yang dikumpulkan berupa peta LPI skala 1 : 50.000 dan Peta Rupa Bumi Indonesia skala 1 : 50.000. Dari kedua peta tersebut dilakukan overlay (tumpang susun) untuk penarikan batas laut dengan cara kartometrik yang mengikuti aturan yang ditetapkan. Dari penarikan ini akan muncul beberapa alternatip batas yang dapat dipakai.

Alternatip batas tersebut dianalisis yang akhirnya akan didapatkan kesimpulan. Dagram alir penelitian dapat dilihat pada Gmbar 2.

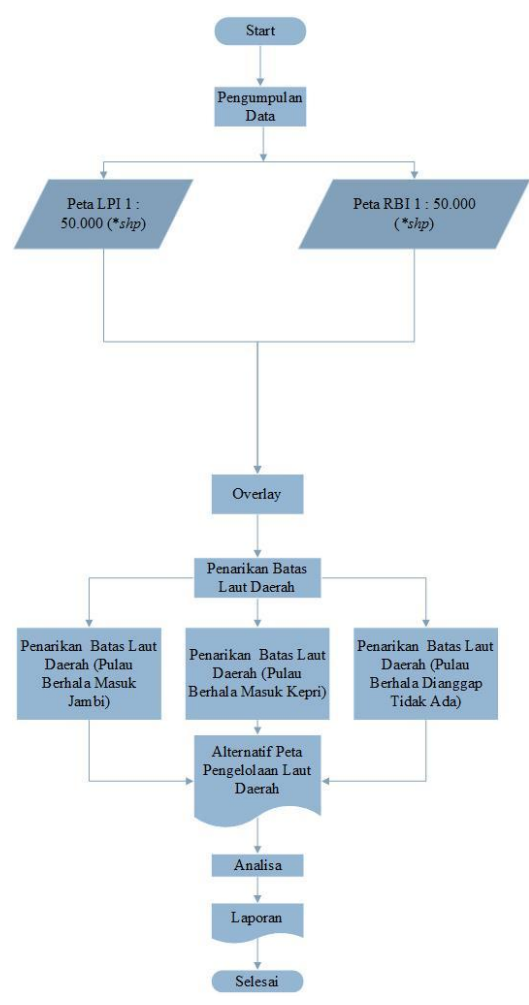

Gambar 2 Diagram Alir Penelitian 
Penjelasan diagram alir penelitian :

a. Pada tahapan yang pertama adalah pengumpulan data - data yang digunakan untuk menunjang penelitian. Data yang dikumpulkan berupa peta yang memuat wilayah yang akan menjadi objek penelitian.

b. Melakukan overlay dari data yang didapat dimana datum, sistem proyeksi dan skalanya harus sama.

c. Menentukan titik dasar pada wilayah Pulau Berhala yang menjadi sengketa antara Provinsi Kepulauan Riau dan Provinsi Jambi.

d. Membuat alternatif peta terkait sengketa yang terjadi berdasarkan Permendagri Nomor 76 Tahun 2012 dengan metode kartometrik.

e. Melakukan analisis dari peta yang telah dibuat mengenai pengelolaan wilayah laut antara Provinsi Jambi dan Kepulauan Riau.

f. Menyampaikan hasil dari analisis yang telah didapatkan.

\section{HASIL DAN ANALISA}

\section{Hasil Penentuan Titik Kartometrik}

Sebelum melakukan penarikan batas secara kartometrik terlebih dahulu dilakukan penentuan titik - titik kartometrik. Penentuan titik kartometrik ini dilakukan di atas peta skala terbesar yang tersedia. Penentuan titik dasar harus mencolok, tidak terlalu banyak memotong daratan dan mudah dilihat. Penetuan titik dilakukan dengan menggunakan prinsip 3 point circle atau 3 titik dengan jarak yang sama. Titik selanjutnya ditentukan oleh dua titik terakhir. Titik - titik yang dipilih kemudian dihubungkan dengan pusat lingkaran yang sama untuk membentuk garis konstruksi. Dari titik pada pusat lingkaran yang satu dengan yang lainnya apabila dihubungkan akan membentuk sebuah garis batas. Dalam penetuan titik kartomertik dilakukan dengan menggunakan AutoCAD Civil 3D Land Desktop Companion 2009.

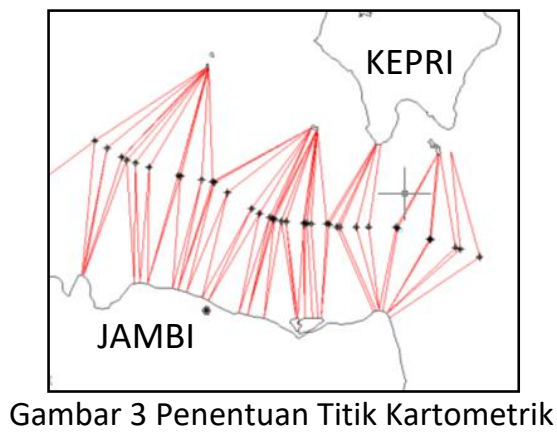

Gambar 3 merupakan titik-titik kartometrik yang terletak antara dua daerah yang akan ditentukan batas wilayahnya.

\section{Hasil Penarikan Garis Batas}

Prinsip yang digunakan dalam penentuan batas pengelolaan wilayah laut ini adalah garis tengah (median line). Prinsip median line digunakan karena jarak antara Provinsi Jambi dengan Provinsi Kepulauan Riau kurang dari dua kali 12 mil laut dan lokasinya saling berhadapan.

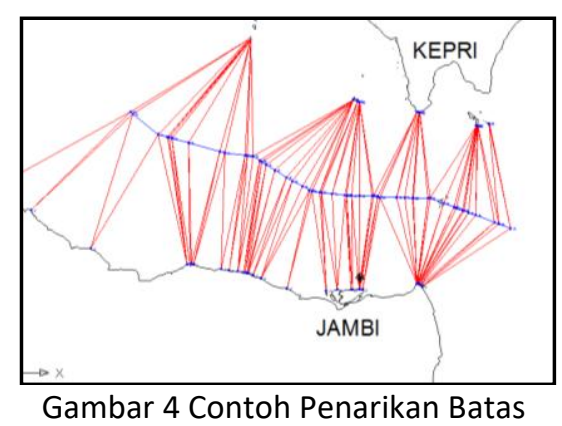

Gambar 4 merupakan contoh penarikan batas dari titik - titik kartometrik yang dibuat dengan metode 3 point circle. Dalam penelitian ini didapatkan 3 alternatif penarikan batas.

\section{Analisa Hasil Penarikan Batas}

Dari penarikan batas yang dilakukan didapatkan tiga alternatif sebagai berikut :

1. Garis batas dimana Pulau Berhala dianggap tidak ada

Apabila Pulau Berhala dianggap tidak ada maka akan di dapatkan Pulau Berhala terbagi menjadi dua yaitu dengan luas 384576,947 $\mathrm{m}^{2}$ dari sisi Jambi dan luas $128195,775 \mathrm{~m}^{2}$ dari sisi Kepulauan Riau serta didapatkan titik kartometrik pada garis batas sebanyak 36 titik. 


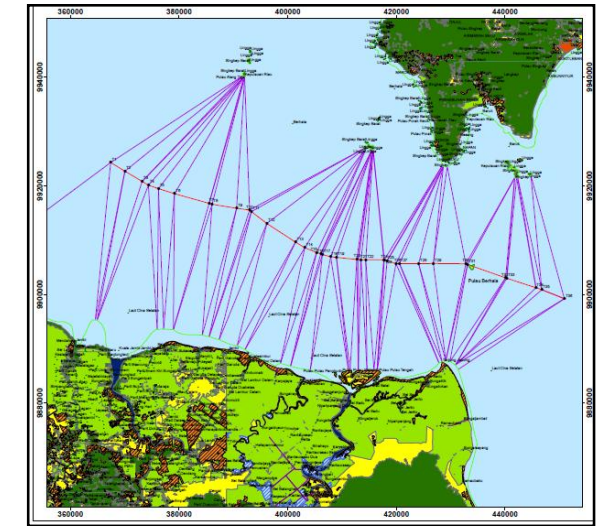

Gambar 5 Hasil Penarikan Batas Pulau Berhala Dianggap Tidak Ada

2. Garis batas dimana Pulau Berhala masuk Provinsi Jambi

Pulau Berhala masuk dalam Provinsi Jambi di dapatkan titik kartometrik pada garis batas sebanyak 38 titik.

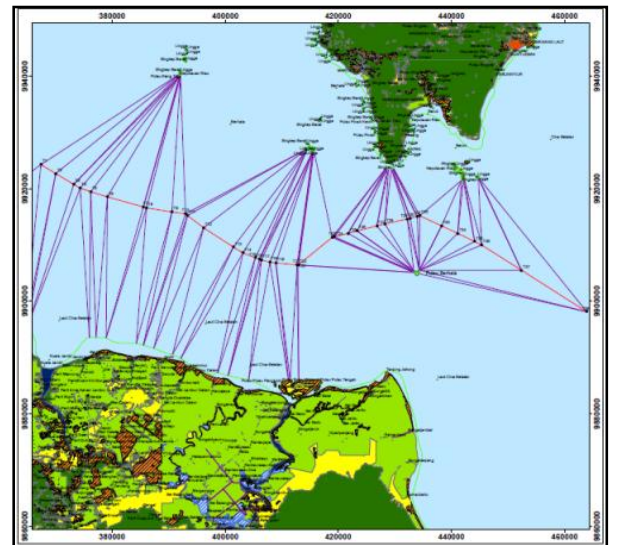

Gambar 6 Hasil Penarikan Batas Pulau Berhala Masuk Jambi

3. Garis batas dimana Pulau Berhala masuk Kepri Pulau berhala masuk dalam Provinsi Kepri maka akan di dapatkan titik kartometrik pada garis batas sebanyak 37 titik .

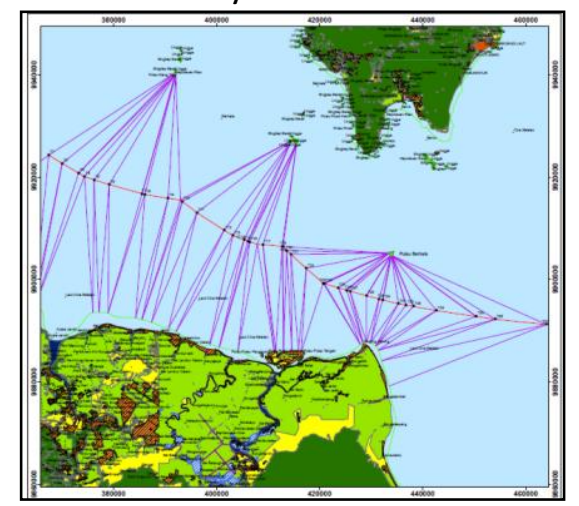

Gambar 7 Hasil Penarikan Batas Pulau Berhala Masuk Kepri

\section{KESIMPULAN}

Berdasarkan hasil dari pengolahan dan analisa yang telah dilakukan dalam penelitian ini didapatkan kesimpulan sebagai berikut.

Analisa zona :

a. Didapatkan Pulau Berhala terbagi menjadi dua yaitu dengan luas $384576,947 \mathrm{~m}^{2}$ dari sisi Jambi dan luas $128195,775 \mathrm{~m}^{2}$ dari sisi Kepulauan Riau. Luas wilayah laut yang bertampalan terbagi menjadi dua, dari sisi Provinsi Jambi memiliki luas $129,064 \mathrm{~km}^{2}$ dan Provinsi Riau memiliki luas 133,442 $\mathrm{km}^{2}$.

b. Pulau Berhala Masuk Jambi. Luas wilayah laut yang bertampalan terbagi menjadi dua, dari sisi Provinsi Jambi memiliki luas $426,992 \mathrm{~km}^{2}$ dan Provinsi Riau memiliki luas $556,787 \mathrm{~km}^{2}$.

c. Pulau Berhala Masuk Kepri . Luas wilayah laut yang bertampalan terbagi menjadi dua, dari sisi Provinsi Jambi memiliki luas $434,721 \mathrm{~km}^{2}$ dan Provinsi Riau memiliki luas $411,818 \mathrm{~km}^{2}$.

\section{UCAPAN TERIMA KASIH}

Ucapan terima kasih disampaikan kepada Badan Informasi Geospasial (BIG) telah menyediakan data dalam penelitian ini.

\section{DAFTAR PUSTAKA}

Abdullah, Rozali. 2012. "Perjuangan Gigih Rajyat Jambi Mempertahankan Gugusan Pulau Berhala".

Badan Informasi Geospasial. "Indonesia Memiliki 13.466 Pulau yang Terdaftar dan Berkoordinat". <http://www.bakosurtanal.go.id/beritasurta/show/indonesia-memiliki-13-466-pulauyang-terdaftar-dan-berkoordinat>. Dikunjungi pada tanggal 29 Januari 2017, jam 19.00

Kementrian Dalam Negeri. 2012 a. "Peraturan Menteri Dalam Negeri Republik Indonesia Nomor 76 Tahun 2012 Tentang Pedoman Penegasan Batas Daerah". Jakarta. 